\title{
Regulation and Genetics of Amino Acid Transport
}

\author{
DALE L. OXENDER, ${ }^{a}$ ELLEN J. COLLARINI, ${ }^{a}$ \\ MARK A. SHOTWELL, ${ }^{b}$ CARMEN D. LOBATON, ${ }^{c}$ \\ ALFREDO MORENO, ${ }^{c}$ AND GEORGE S. CAMPBELL ${ }^{a}$ \\ ${ }^{a}$ Department of Biological Chemistry \\ University of Michigan \\ Ann Arbor, Michigan 48109 \\ ${ }^{b}$ Department of Genetics \\ The Hospital for Sick Children \\ Toronto, Ontario, Canada M5G 1 X8 \\ ${ }^{c}$ Facultad de Medicina \\ Departmento de Fisiologia y Bioquimica \\ Valladolid, Spain
}

The major transport systems for the uptake of neutral amino acids in mammalian cells have been designated $\mathrm{A}, \mathrm{ASC}$, and $\mathrm{L}^{1,2}$ The transport systems and their regulation have been characterized in Chinese hamster ovary (CHO) cells. ${ }^{3,4}$ System $\mathrm{A}$ is sodium-dependent, subject to trans-inhibition, and serves for the uptake of amino acids with short, polar, or linear side chains. System ASC is also sodium dependent and has a strong preference for alanine, serine, and cysteine. In the $\mathrm{CHO}$ cell, the ASC system shows a somewhat broader specificity than that found in the Ehrlich cell. ${ }^{2}$ Unlike System A, System ASC does not tolerate $N$-methylated substrates such as 2-methylaminoisobutyric acid (MeAIB). System $L$ is sodium-independent and serves for the uptake of branched-chain and aromatic amino acids. We operationally define the systems as follows: System A can be represented by the sodium-dependent uptake of $0.2 \mathrm{mM}$ 2-aminoisobutyric acid (AIB) that is inhibited by $25 \mathrm{~m} M$ MeAlB; System ASC, the sodium-dependent uptake of $0.2 \mathrm{~m} M$ L-alanine that is not inhibited by 25 $\mathrm{m} M \mathrm{MeAIB}$; and System L, the sodium-independent uptake of $0.2 \mathrm{~m} M \mathrm{~L}$-leucine that is inhibited by $10 \mathrm{mM}$ 2-aminobicyclo-[2,2,1]-heptane-2-carboxylic acid (BCH). ${ }^{3}$

Although the systems have a preferred set of substrates, they do have overlapping specificities. FigURE 1 shows the contributions of these systems to the uptake of individual amino acids in CHO-K1 cells. This overlap makes the study of transport systems in isolation difficult. The availability of mutations in one or more of the transport systems would greatly facilitate the study of the function and regulation of the transport systems. We are currently combining genetic approaches with kinetic studies using $\mathrm{CHO}$ cells because of the relative ease with which mutants can be obtained from these cells. Furthermore, $\mathrm{CHO}$ cells can be used to form interspecies hybrids with human cells. ${ }^{5}$ The hamster-human hybrid cells preferentially segregate the human chromosomes, permitting the assignment of a phenotype to a particular chromosome. In the present study, we have isolated and characterized CHO mutants defective in the regulation of System $L^{6}$ and mutants with reduced System $L$ transport activity. We have also used hamster-human hybrids to map System L transport activity to human chromosome $20{ }^{7}$ 


\section{MATERIALS AND METHODS}

\section{Cell Lines and Culture Methods}

The CHO-K1 and CHO-tsH1 cell lines were obtained from Dr. L. H. Thompson of the Lawrence Livermore Laboratory, Livermore, California. These cell lines were maintained as described previously. ${ }^{3,6}$ The temperature-resistant cell lines $\mathrm{C11}$, C11B6, D10, and F10 were isolated in our lab and maintained as described previously. ${ }^{6}$ The transport mutant cell lines $\mathrm{C} 5, \mathrm{C} 5 \mathrm{~F} 6, \mathrm{C} 9$, and D3 were maintained in Eagle's minimal essential medium (MEM) containing Earle's salts and nonessential amino acids, supplemented with 5\% (vol/vol) fetal calf serum (KC Biological, Lenexa, KS),

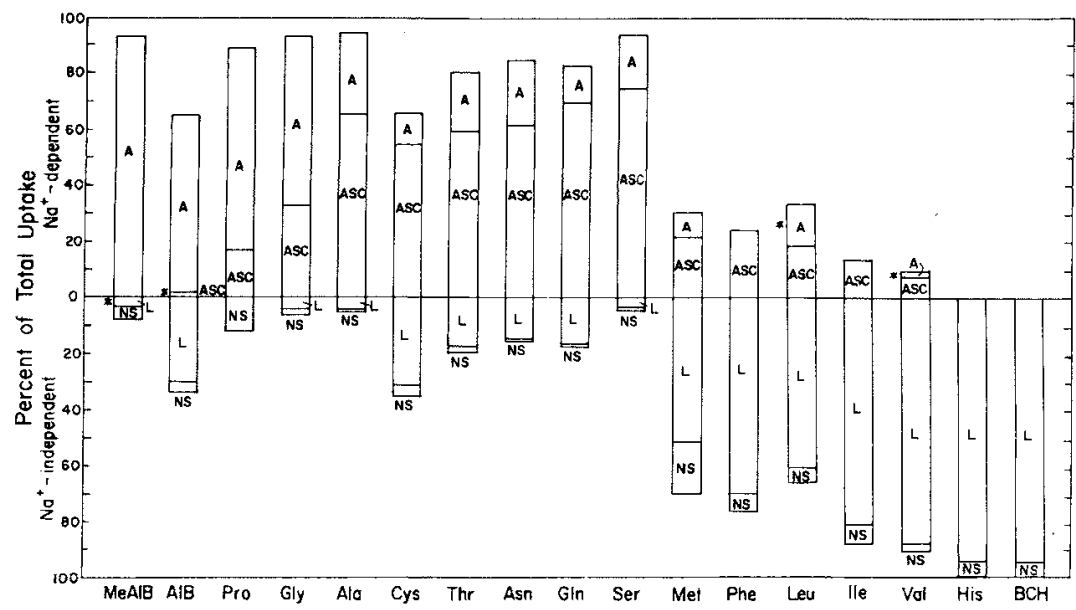

FIGURE 1. Total uptake of neutral amino acids in CHO-K1 cells divided into contributions by the three transport systems. Cells were plated and grown in MEM at $37^{\circ} \mathrm{C}$ as described in Materials and Methods. The cells were then assayed for the uptake of $0.2 \mathrm{mM}$ of the indicated amino acid for one minute at $37^{\circ} \mathrm{C}$. The total uptake was divided into the individual transport components as described previously. ${ }^{3}$ The components are expressed as a percentage of the total uptake in $\mathrm{Na}^{+}$-containing buffer. Asterisks indicate statistically insignificant values. NS, nonsaturable component. The values are the averages of three determinations. (Reprinted from Shotwell et al. ${ }^{3}$ )

$2.2 \mathrm{~g} / \mathrm{l} \mathrm{NaHCO}$, and with the following eight amino acids to the indicated final concentrations: $1 \mathrm{~m} M$ L-histidine, $2 \mathrm{~m} M$ L-isoleucine, $2 \mathrm{~m} M$ L-leucine, $0.5 \mathrm{~m} M$ L-methionine, $1 \mathrm{~m} M$ L-phenylalanine, $0.25 \mathrm{~m} M$ L-tryptophan, $1 \mathrm{~m} M$ L-tyrosine, and 2 $\mathrm{m} M$ L-valine. This medium is referred to as $5 \times \mathrm{MEM}$. The cell line $\mathrm{CHO}$-ts025C1 and the hamster-human hybrid cell line $158 \mathrm{CnpT}-1$ were the generous gifts of Dr. R. E. Giles of the Advanced Genetics Research Institute, Oakland, California. These cell lines and the segregants of the hamster-human hybrid line were maintained as described previously. ${ }^{7}$ All cultures were maintained at $\mathrm{pH} 7.4$ in a humidified atmosphere of $95 \%$ air and $5 \% \mathrm{CO}_{2}$. Every three months, cultures were discarded and fresh cultures were started from stock frozen in liquid nitrogen.

The sodium-containing buffer was Dulbecco's phosphate-buffered saline (PBS) at 
pH 7.4, consisting of $137 \mathrm{mM} \mathrm{NaCl}, 2.7 \mathrm{mM} \mathrm{KCl}, 10.6 \mathrm{mM} \mathrm{Na}_{2} \mathrm{HPO}_{4}$, and $1.5 \mathrm{mM}$ $\mathrm{KH}_{2} \mathrm{PO}_{4}$. The sodium-free buffer had equimolar amounts of choline chloride and choline phosphate in place of $\mathrm{NaCl}$ and $\mathrm{Na}_{2} \mathrm{HPO}_{4}$, respectively. This buffer is referred to as $\mathrm{PBC}$ and was prepared as described previously. ${ }^{3}$ For starvation experiments and for depletion and washing steps in transport assays, PBS and PBC were supplemented with $5.6 \mathrm{mM}$ D-glucose, $0.49 \mathrm{mM} \mathrm{MgCl}$, and $0.68 \mathrm{mM} \mathrm{CaCl}$. These buffers are referred to as PBS-GMC and PBC-GMC, respectively. All buffers were at pH 7.4.

\section{Transport Assays}

Cells were plated in the appropriate medium at the indicated temperatures in Costar 24-well culture dishes with 1.3-1.5 × $10^{5}$ cells per well. Cells were allowed to recover for $16-24$ hours. We used the cluster tray assay as described previously, ${ }^{3,8}$ except that in FIGURES 3 and 6 the depletions were for 40 minutes with a change to fresh PBC-GMC at 20 minutes. For FIGURES 1, 2, and 3, the depletions were done at $37^{\circ} \mathrm{C}$, and for Figures $4,5,6$, and 8 , depletions were done at $34^{\circ} \mathrm{C}$.

\section{Cytogenetic Procedures}

Giemsa alkaline differential staining (G-11) and the trypsin-Giemsa (G-banding) method of staining were carried out using described procedures.,10

\section{Isozyme Analysis}

Procedures for the enzyme assays are as described previously. ${ }^{\text {? }}$

\section{Materials}

Radioactive amino acids were obtained from Amersham Corp., ICN, and New England Nuclear. Unlabeled amino acids (L-isomers) were obtained from Sigma. 2-Aminobicyclo-[2,2,1]-heptane-2-carboxylic acid was obtained from CalbiochemBehring Corp. $N$-methyl- $N$ '-nitro- $N$-nitrosoguanidine, ethyl methanesulfonate and cycloheximide were obtained from Sigma.

\section{RESULTS}

\section{Regulation}

Mammalian cells adapt to changes in the availability of amino acids by regulating the activity of their transport systems. ${ }^{11,12}$ The regulation of System A transport has been well characterized in many cell types, including CHO cells. ${ }^{11,12}$ Upon starvation in amino acid-free medium, CHO-K 1 cells showed an almost twofold increase in System A activity within six hours (FIG. 2). The presence of a single System A amino acid, even the nonmetabolizable substrate 2-methylaminoisobutyric acid, prevented the starvation-induced derepression. The inhibition of the derepression by cycloheximide suggests that de novo protein synthesis may be necessary. 
Earlier studies on the regulation of System A transport had also shown that System $\mathrm{L}$ transport activity is not regulated. ${ }^{13,14}$ Upon starvation in amino acid-free medium, there was generally no change in System L transport activity. Severe starvation of CHO-K 1 cells for a single System L amino acid (for example, less than $10 \mu M$ leucine), however, resulted in a three- to fourfold increase of leucine transport activity (FIG. 3). ${ }^{15}$ Additional dialysis of the commercially available dialyzed fetal calf serum was required to sufficiently starve the cells of leucine. The increase in leucine transport activity following starvation was lost within one hour after refeeding.

Regulation of System $\mathrm{L}$ is also seen in the CHO mutant cell line CHO-tsH1, which has a temperature-sensitive leucyl-tRNA synthetase. ${ }^{16,17}$ At high temperatures $\left(37^{\circ}-\right.$
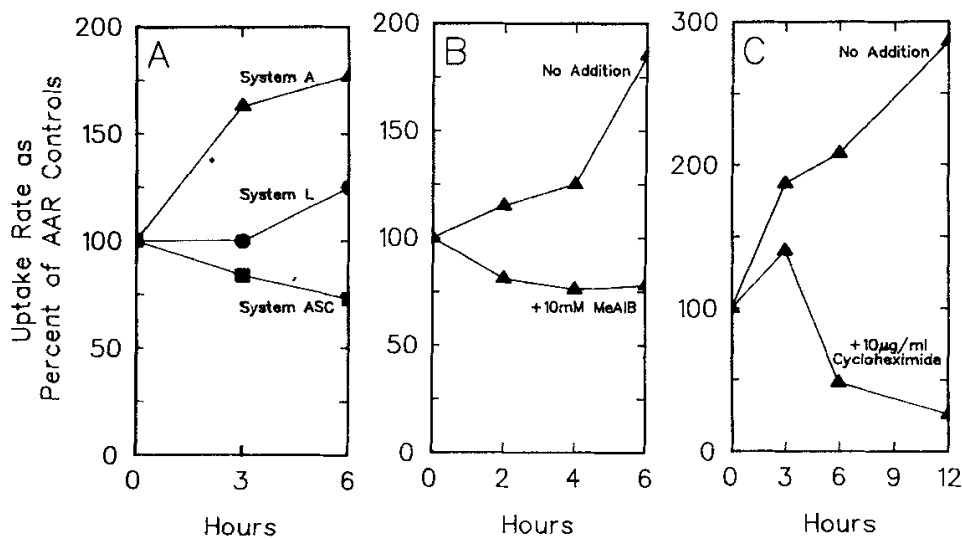

FIGURE 2. Effect of starvation for amino acids on transport activity in CHO-K1 cells. Cells were plated and grown in MEM at $37^{\circ} \mathrm{C}$ as described in MATERIALS and METHODS. The medium was then replaced with either fresh MEM or PBS-GMC supplemented with $5 \%$ dialyzed fetal calf serum. Uptake assays were carried out at the indicated times. The values are expressed as a percentage of the activity of cells kept in MEM, referred to here as amino acid-rich medium (AAR). A, activities of the three systems after starvation. The values are the averages of six determinations. B, $\mathrm{Na}^{+}$-dependent, 5-min uptake of $0.2 \mathrm{~m} M$ MeAIB in PBS by cells incubated in PBS-GMC supplemented with $5 \%$ dialyzed fetal calf serum with or without $10 \mathrm{mM}$ MeAIB. The values are the averages of three determinations. $\mathrm{C}, \mathrm{Na}^{+}$-dependent, 5 -min uptake of $0.2 \mathrm{mM}$ MeAIB in PBS by cells incubated in PBS-GMC supplemented with $5 \%$ dialyzed fetal calf serum with or without $10 \mu \mathrm{g} / \mathrm{ml}$ cycloheximide. The values are the averages of three determinations.

$39^{\circ} \mathrm{C}$ ) the cells are starved for leucine because of their inability to charge leucyltRNA. They will not grow at these temperatures unless supplied with relatively high concentrations of leucine in the medium. ${ }^{18}$ When leucine uptake was measured in CHO-tsHl cells after incubation at $38^{\circ} \mathrm{C}$ for several hours, there was a two- to threefold increase in activity over that seen after incubation at $34^{\circ} \mathrm{C}^{19,20}$ The maximum level of derepression was reached within twelve hours. The derepression was specific for System L activity, as shown in FIGURE 4. When the cells were returned to $34^{\circ} \mathrm{C}$, the leucine uptake rate decreased to the original level within six hours. Severe starvation for leucine, either by lowering the leucine concentration in the medium for wild-type cells, or by growing $\mathrm{CHO}$-tsH 1 cells at $37^{\circ}-39^{\circ} \mathrm{C}$, results in a derepression of System L transport activity. 


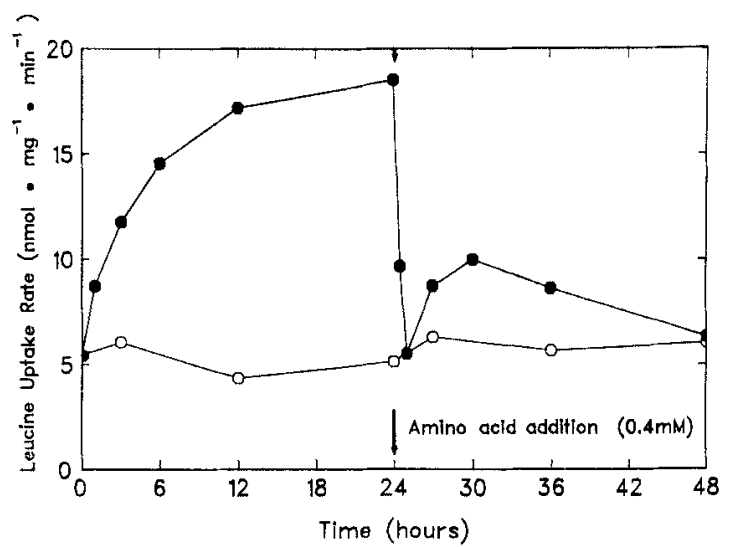

FIGURE 3. Effect of starvation for leucine on leucine uptake in CHO-KI cells. Cells were plated and grown in MEM at $37^{\circ} \mathrm{C}$. The cells were then washed twice with $2 \mathrm{ml}$ of PBS and the medium was either replaced with fresh MEM or with leucine-free MEM supplemented with $5 \%$ extensively dialyzed fetal calf serum. After 24 hours leucine was added to a concentration of 0.4 $\mathrm{m} M$. At various times the 1 -min uptake of $0.2 \mathrm{~m} M$ leucine in $\mathrm{PBC}$ was determined. The values are the averages of four determinations. (O), MEM; (๑), leucine-free MEM.

\section{Regulatory Mutants}

We have isolated temperature-resistant cells from the $\mathrm{CHO}-\mathrm{tsH} \mathrm{l}$ cell line that are defective in the regulation of System $L$ transport. ${ }^{6}$ After mutagenesis of a population of CHO-tsH 1 cells with $N$-methyl- $N^{\prime}$-nitro- $N$-nitrosoguanidine, the cells were grown at $38^{\circ} \mathrm{C}$ in MEM $(0.4 \mathrm{mM}$ leucine). After several passages, the temperature was raised to $39^{\circ} \mathrm{C}$. After several additional passages, clones were isolated and grown in leucine-free MEM supplemented with $0.2 \mathrm{~m} M$ leucine at $39^{\circ} \mathrm{C}$. Survivors were screened for leucine transport activity. The ten clones with the highest leucine transport activity were subjected to further selection by growing them in leucine-free MEM supplemented

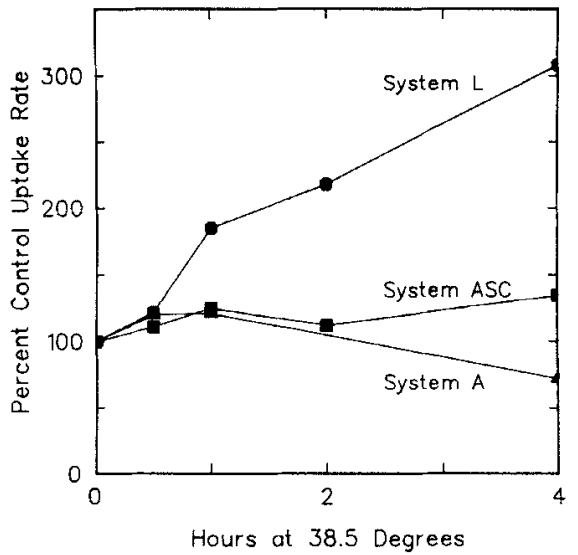

FIGURE 4. Specificity of the temperaturedependent derepression in the cell line CHOts H1. Cells were plated and grown in MEM at $34^{\circ} \mathrm{C}$. Half the dishes were then shifted to $38.5^{\circ} \mathrm{C}$ and the other half left at $34^{\circ} \mathrm{C}$. The transport systems activities were determined at various times. The data are expressed as the percentage of control values at time zero. The values are the averages of four determinations. (Reprinted from Shotwell et al. ${ }^{20}$ ) 
with $0.1 \mathrm{mM}$ leucine at $39^{\circ} \mathrm{C}$. The three cloned cell lines with the highest leucine transport activity (C11, D10, F10) were subcloned to obtain a homogeneous population. The temperature-resistant cell lines are routinely maintained under selective conditions (at $39^{\circ} \mathrm{C}$ in leucine-free $\mathrm{MEM}$ supplemented with $0.1 \mathrm{mM}$ leucine).

FIGURE 5 compares the uptake of leucine by the temperature-resistant cell lines, $\mathrm{C} 11$ and $\mathrm{F} 10$, to that of the parental cell line, $\mathrm{CHO}$-tsH1, after a six-hour incubation at either $34^{\circ} \mathrm{C}$ or $38.5^{\circ} \mathrm{C}$. $\mathrm{CHO}$-tsH1 cells showed a two- to threefold increase in leucine uptake when incubated at $38.5^{\circ} \mathrm{C}$ as compared to cells incubated at $34^{\circ} \mathrm{C}$. The $\mathrm{C} 11$ and $\mathrm{F} 10$ cell lines had much higher leucine uptake activities than $\mathrm{CHO}-\mathrm{tsH} 1$ cells at both temperatures, with no significant increase in the activities when incubated at $38.5^{\circ} \mathrm{C}$ as compared to cells incubated at $34^{\circ} \mathrm{C}$. The increase in leucine transport activity in the $\mathrm{C} 11, \mathrm{D} 10$, and F10 cell lines was specific for System $\mathrm{L}$ at both temperatures. The activities of System A and ASC were not changed significantly in the $\mathrm{C} 11, \mathrm{DlO}$, and $\mathrm{F} 10$ cell lines in comparison to $\mathrm{CHO}-\mathrm{tsH} 1$ cells.

Measurement of the kinetic parameters of leucine uptake showed that the increased transport activity in the temperature-resistant cell lines was accompanied by

FIGURE 5. Leucine uptake by the cell line $\mathrm{CHO}$-tsHl and two temperature-resistant cell lines. Cells were plated and grown in MEM at $34^{\circ} \mathrm{C}$. Half the dishes were shifted to $38.5^{\circ} \mathrm{C}$ and the other half left at $34^{\circ} \mathrm{C}$. After 6 hours, the 30-sec uptake of 0.2 $\mathrm{m} M$ leucine in PBC was determined. Values are the averages of four determinations.

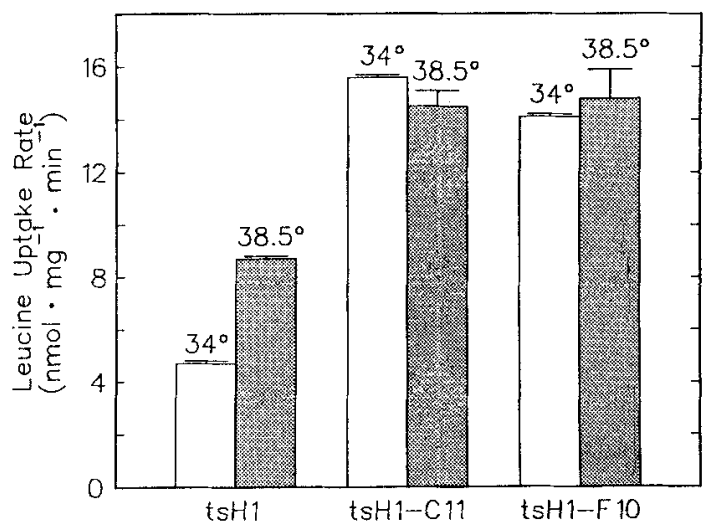

a two- to threefold increase in the $\mathrm{V}_{\max }$ of leucine uptake with no significant change in the $K_{\mathrm{m}}$ when compared to $\mathrm{CHO}-\mathrm{tsH} 1$ cells at $34^{\circ} \mathrm{C}$. At $38.5^{\circ} \mathrm{C}$ the $\mathrm{V}_{\max }$ of leucine uptake in $\mathrm{CHO}$-tsH1 cells increased threefold over that seen at $34^{\circ} \mathrm{C}$, while in the temperature-resistant cell lines there was only a small increase.

We measured the 20-minute steady-state accumulation of several amino acids in the $\mathrm{CHO}-\mathrm{tsH} \mathrm{l}$ and the temperature-resistant cell lines. The accumulation of proline, mainly transported by System A, and the accumulation of alanine and serine, mainly transported by System ASC, was not significantly different in the temperatureresistant cell lines when compared to the CHO-tsH1 cell line. However, the steadystate accumulation of leucine, isoleucine, and valine, mainly transported by System $\mathrm{L}$, was increased 1.5-3-fold in the temperature-resistant cell lines when compared to the CHO-tsH1 cell line. These results suggest that the increase in System L transport activity in the temperature-resistant lines leads to increased intracellular steady-state levels of System $L$ amino acids.

We examined the possibility that the temperature-resistant cells resulted from a reversion of the leucyl-tRNA synthetase. An examination of the thermolability of the 
leucyl-tRNA synthetase in the temperature-resistant lines suggested that the temperature resistance was not related to a reversion of the synthetase.

Several criteria must be met in order to consider a change in transport the result of a mutation. One of these criteria is that the alteration would be expected to persist after the removal of selection pressure. ${ }^{21}$ When the temperature-resistant lines were grown under nonselective conditions (at $34^{\circ} \mathrm{C}$ in $\mathrm{MEM}$, which has $0.4 \mathrm{mM}$ leucine) for as long as 62 days, the System $L$ transport activity remained the same as in those cells kept under selective conditions.

We have concluded that the increase in the activity of System $L$ transport in the temperature-resistant lines is the result of a stable mutation in the regulation of System L transport. The kinetic data are consistent with, but do not prove, an increase in the number of active transport carriers in these cell lines, with no change in the affinity of the carrier. The increase in System L transport activity in these cell lines also leads to an elevated intracellular steady-state accumulation of System L amino acids, complementing the leucyl-tRNA synthetase defect and resulting in temperature resistance. These results are consistent with the conclusion that the temperatureresistant cell lines have a defect in a negative regulatory element leading to constitutively derepressed System L transport activity.

A similar type of mutant defective in the regulation of System A transport has been reported by Englesberg. ${ }^{22}$ To isolate this mutant, $\mathrm{CHO}$ pro- cells were grown in the presence of high concentrations of alanine, which inhibits their growth by limiting proline uptake. ${ }^{23}$ Alanine-resistant cells were obtained that had constitutively derepressed System A transport activity. This higher System A transport activity apparently allowed the cells to overcome proline starvation. These types of mutants contribute to our understanding of transport regulation and can be used in the selection of other types of mutants, as described in the following section.

\section{Transport Mutants}

We are attempting to isolate and characterize mutants defective in amino acid transport in order to identify the components of the transport systems. To obtain transport mutants in System L, we have designed a tritium-suicide selection strategy. Tritium-suicide selections using radioactive amino acids have been used successfully to obtain protein synthesis mutants similar to the CHO-tsH1 cell line. ${ }^{24,25}$ We have modified the procedure in the following way to select for transport mutants. A tritiated amino acid is used as a toxic substrate. Cells that take up the radioactive amino acid will be subjected to internal radiation and will be killed. However, if in a population there are mutants with a defective transport system, these cells will take up much less of the radioactive amino acid, experience less internal radiation, and survive the procedure. To make sure we are selecting for transport mutants and not for protein synthesis mutants, the exposure to the tritiated amino acid is brief (three minutes) and the cells are frozen as quickly as possible.

Initial attempts to obtain transport mutants from normal CHO-K1 cells using this type of selection did not yield mutants with significant transport defects. It is possible that the ability of these cells to regulate System L transport activity did not permit the selection of transport-defective mutants. We then decided to take advantage of the regulatory mutants isolated in our lab and described in the previous section. Since the regulatory mutants have a much higher System $L$ transport activity, they are more sensitive to toxic substrates. Furthermore, since they have lost the ability to regulate System $L$ activity, a low transport mutant derived from these cells would also no longer be able to regulate System $L$ activity. Finally, mutants from these parental cells would 
still have the temperature-sensitive leucyl-tRNA synthetase, a condition which will be to our advantage in future selections.

There were two points to consider in designing the selection. First, since System L serves for the transport of most of the essential amino acids, a mutant with low System $\mathbf{L}$ transport activity may not survive unless supplemented with these amino acids. Therefore, after mutagenesis the cells were grown in MEM supplemented with three to five times the normal concentrations of essential System L amino acids. Second, the parental cells are able to survive at $39^{\circ} \mathrm{C}$, presumably because their elevated System L transport activity compensates for the temperature-sensitive leucyl-tRNA synthetase. Transport-defective mutants would lose the ability to compensate for the defect, so after mutagenesis the cells were grown at $34^{\circ} \mathrm{C}$, the permissive temperature. Approxi-

FIGURE 6. Leucine uptake by the cell line $\mathrm{CHO}$-tsH1, the regulatory mutant cell line $\mathrm{C} 11 \mathrm{~B} 6$, and the low transport cell line C5F6. Cells were plated and grown in $5 \times M E M$ at $34^{\circ} \mathrm{C}$. Cells were then washed with $2 \mathrm{ml}$ of PBS and the medium was replaced with MEM. Half the dishes were placed at $39^{\circ} \mathrm{C}$ and the other half left at $34^{\circ} \mathrm{C}$. After 6 hours the 30 -sec uptake of $50 \mu M$ leucine in PBC was determined. The values are the averages of three determinations.

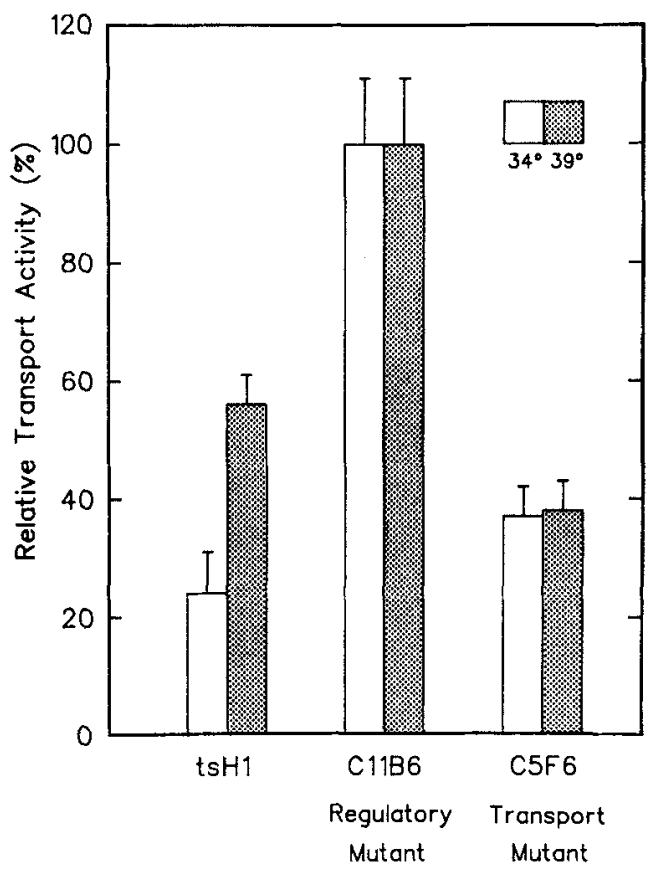

mately $10^{7}$ cells from the $\mathrm{C} 11 \mathrm{~B} 6$ line, a subclone of the regulatory mutant $\mathrm{C} 11$, were mutagenized with $200 \mu \mathrm{g} / \mathrm{ml}$ ethyl methanesulfonate for 16 hours at $39^{\circ} \mathrm{C}$ and then incubated for six to seven days to allow phenotypic expression. After six to seven days, the cells were harvested by trypsinization, centrifuged, washed with PBC-GMC and exposed to $\left[{ }^{3} \mathrm{H}\right.$ ]leucine $\left(80 \mu \mathrm{Ci} / \mathrm{ml}, 2 \times 10^{5}\right.$ cells $\left./ \mathrm{ml}\right)$ in $\mathrm{PBC}$ for three minutes at $37^{\circ} \mathrm{C}$. Sodium was removed in order to limit the uptake of the $\left[{ }^{3} \mathrm{H}\right]$ leucine to System $\mathrm{L}$. The cells were washed with cold PBC-GMC and frozen in $5 \times$ MEM supplemented with $10 \%$ fetal calf serum and $10 \%$ glycerol as quickly as possible. Several days later, the cells were thawed and plated in $5 \times$ MEM supplemented with $10 \%$ fetal calf serum in $100-\mathrm{mm}$ culture dishes at $34^{\circ} \mathrm{C}$. The medium was changed every day for several days to remove dead cells and $\left[{ }^{3} \mathrm{H}\right]$ leucine. The surviving colonies were either picked and transferred or the cells were harvested, diluted, and dispensed one cell per well in a 
96-well dish. The surviving clones were grown up and assayed for leucine uptake. Those with the lowest values were subjected to further study. In one case the population surviving after thawing was mutagenized a second time and subjected to the same procedure. The cell lines C5, C9, and D3 are from this second round of selection. The C5 cell line was subcloned and the subclone with the lowest leucine transport activity $(\mathrm{C} 5 \mathrm{~F} 6)$ was retained. These cells are routinely maintained in $5 \times \mathrm{MEM}$ at $34^{\circ} \mathrm{C}$.

FIGURE 6 shows the uptake of leucine in the cell line CHO-tsH1, the parental cell line $\mathrm{C} 11 \mathrm{~B} 6$, and the low transport cell line C5F6 after a six-hour incubation at either $34^{\circ} \mathrm{C}$ or $39^{\circ} \mathrm{C}$. As shown previously, leucine uptake activity was increased two- to threefold in $\mathrm{CHO}-\mathrm{tsH} 1$ cells when incubated at $39^{\circ} \mathrm{C}$. The regulatory mutant cell line C11B6 showed increased and unregulated leucine uptake. The low transport cell line C5F6 had $37 \%$ and $38 \%$ of the leucine transport activity of C11B6 cells when incubated at $34^{\circ} \mathrm{C}$ and $39^{\circ} \mathrm{C}$, respectively. The cell line C5F6 also showed unregulated leucine transport activity.

We measured the ability of the low transport cell lines to grow on low levels of leucine. Figure 7 shows the growth curves for low transport cell lines C9, D3, and the parental cell line C11B6 grown in leucine-free MEM supplemented with $75 \mu M$ leucine at $39^{\circ} \mathrm{C}$. The low transport cell lines showed limited growth in comparison to the parental cell line. These results support our earlier conclusions about the regulatory mutants. The fact that the low transport mutants are temperature-sensitive shows that the leucyl-tRNA synthetase had not reverted. The low transport mutants are now being characterized further. They may also be used as the starting cells for a selection aimed at amplifying the CHO System $\mathrm{L}$ transport genes.

\section{Mapping of Human Transport Genes}

Somatic cell hybridization studies were initiated based on our early studies on the properties of the CHO-tsHl cell line. Hybrid cells of a temperature-sensitive leucyltRNA synthetase mutant (CHO-ts025C1) and human leukocytes would be expected to become temperature-resistant if they expressed the human leucyl-tRNA synthetase gene or if they expressed human System L transport activity, leading to an increased ability to accumulate leucine. We examined several temperature-resistant hamster-

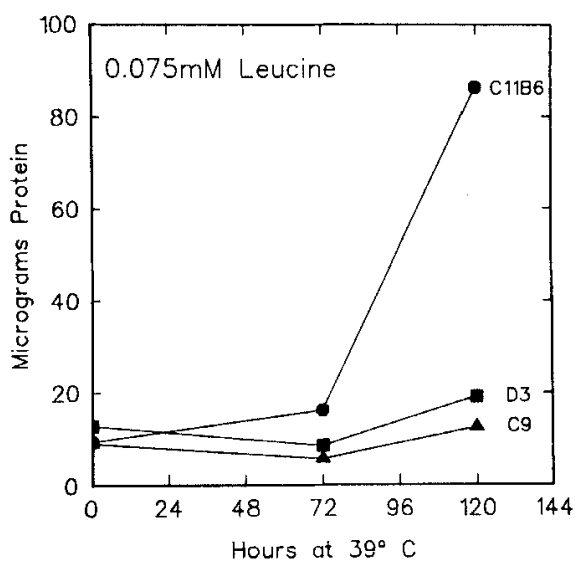

FIGURE 7. Growth of the low transport cell lines $\mathrm{C} 5$ and D3 at $39^{\circ} \mathrm{C}$. Cells were plated at $2.2 \times 10^{4}$ cells per well in 24-well culture dishes in $5 \times \mathrm{MEM}$ at $34^{\circ} \mathrm{C}$. After recovery (time zero), cells were washed two times with $2 \mathrm{ml}$ of PBS. The medium was replaced with leucine-free MEM supplemented with 75 $\mu M$ leucine and $5 \%$ dialyzed fetal calf serum. The cells were incubated at $39^{\circ} \mathrm{C}$ for the indicated times. The cells were then washed twice with $2 \mathrm{ml}$ of PBS and precipitated with $220 \mu \mathrm{l}$ of $10 \%$ trichloroacetic acid. The precipitate was dissolved in $100 \mu 11 \mathrm{~N} \mathrm{NaOH}$ and the protein determined.$^{30}$ The values are the averages of four determinations. 


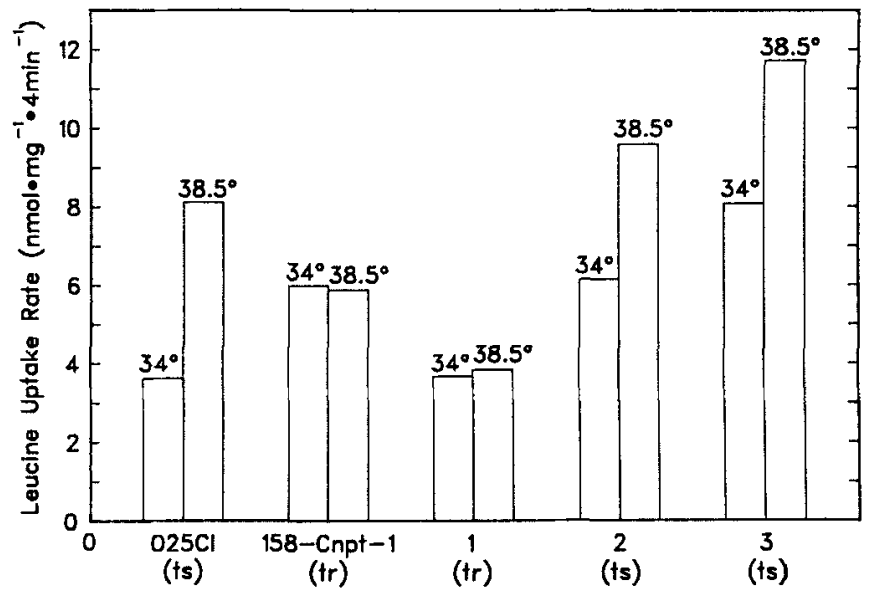

FIGURE 8. Leucine uptake by several segregants of the hamster-human hybrid cell line $158 \mathrm{CnpT}-1$. Cells were plated and grown for 6 hours in MEM at $34^{\circ} \mathrm{C}$. Half the dishes were shifted to $38.5^{\circ} \mathrm{C}$ and the other half kept at $34^{\circ} \mathrm{C}$. After 12 hours, the 4-min uptake of $0.1 \mathrm{mM}$ leucine in $\mathrm{PBC}$ was determined. The values are the averages of four determinations. tr, temperature-resistant; ts, temperature-sensitive. (Reprinted with permission from Shotwell $e t$ al. 1984. Fed. Proc. 43: 2269-2272.)

human hybrids obtained from Giles et al. that were used to assign the chromosomal location of the human leucyl-tRNA synthetase to chromosome $5{ }^{26,27}$ We measured the leucine uptake of several of these hybrids and found that the hybrid line $158 \mathrm{CnpT}-1$ had a two- to threefold increase in leucine transport activity over that seen in CHO-ts025C1 cells. ${ }^{7}$ This increase was specific for System $\mathrm{L}$ activity. The activities of systems A and ASC were not significantly changed. The hybrid cell line accumulated higher steady-state levels of intracellular leucine and other System $\mathrm{L}$ amino acids than did $\mathrm{CHO}$-ts025 $\mathrm{Cl}$ cells, but the accumulation of alanine in the hybrid cells was not significantly different than that in CHO-ts $025 \mathrm{C} 1$ cells.

Cytogenetic analysis was carried out on the hamster-human hybrid cell line using the alkaline Giemsa (G-11) method to distinguish four human chromosomes and three human translocations in the hamster chromosomes. The trypsin-Giemsa (G-banding) method was used to identify these four chromosomes as numbers $4,5,20$, and $21 .^{9,10}$

To determine if the high leucine transport activity and the temperature resistance were from independent human chromosomal loci, the hybrid cell line $158 \mathrm{CnpT}-1$ was subjected to conditions that allowed further segregation of the human chromosomes. The cells were grown under permissive conditions (at $34^{\circ} \mathrm{C}$ in $\mathrm{MEM}$ supplemented with $2 \mathrm{~m} M$ leucine) to allow survival of segregants that had lost human chromosome 5 . The cells were treated with a sublethal dose of colcemid $(0.02 \mu \mathrm{g} / \mathrm{ml})$ for 30 hours at $34^{\circ} \mathrm{C}$ to facilitate the segregation. After recovery from the colcemid ( 42 hours) the cultures were subcloned. The clones were assayed for leucine uptake and temperatureresistant growth. The segregants fell into four classes: (1) low leucine transport activity and temperature resistance; (2) high leucine transport activity and temperature sensitivity; (3) extra-high leucine transport activity and temperature sensitivity; and (4) low leucine transport activity and temperature sensitivity. FIGURE 8 compares the leucine uptake activity of segregants from the first three classes to that of CHOts $025 \mathrm{Cl}$ cells and the hamster-human hybrid cell line $158 \mathrm{CnpT}-1$. Growth curves 


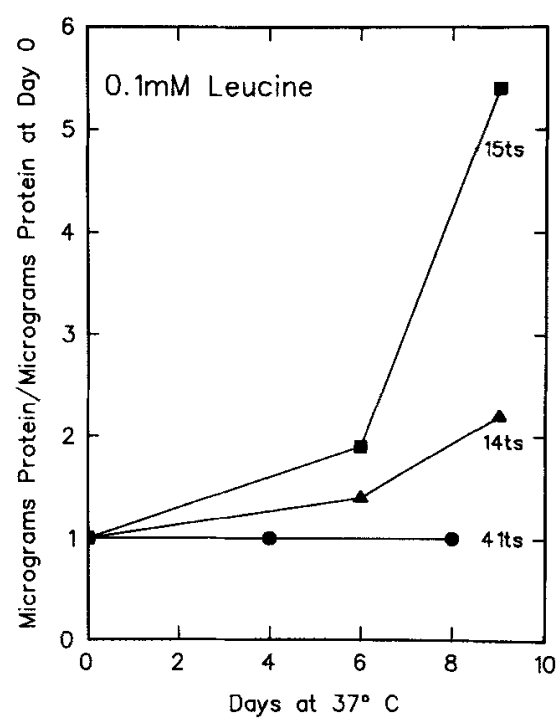

FIGURE 9. Growth of segregants of the hamster-human hybrid cell line $158 \mathrm{CnpT}-1$ at $37^{\circ} \mathrm{C}$. Cells were plated at $7.5 \times 10^{4}$ cells per well in 24-well culture dishes in MEM at $34^{\circ} \mathrm{C}$. After recovery (time zero), cells were washed with $1 \mathrm{ml}$ PBS. The medium was replaced with leucine-free MEM supplemented with $0.1 \mathrm{mM}$ leucine and $5 \%$ dialyzed fetal calf serum. The cells were incubated at $37^{\circ} \mathrm{C}$ for the indicated times. The samples were then prepared as described in FIGURE 7. The values are the averages of two experiments with six determinations each.

showed a slight, but significantly higher temperature resistance in classes 2 and 3 (FIG. 9 ). The segregant cell line 14ts is from class 2 , the segregant cell line 15 ts is from class 3 , and the segregant cell line 41 ts is from class 4 .

Karyotypes of the segregants were carried out using G-11 staining and G-banding techniques. The cytogenetic analysis showed that the primary temperature resistance was correlated with the presence of human chromosome 5 , confirming the earlier reports. ${ }^{26,27}$ The loss of the high leucine transport activity was associated with the loss of one of the two small human chromosomes, 20 or 21 .

To distinguish between chromosomes 20 and 21 , we assayed for the presence of the marker enzymes for chromosomes 20 and 21 , adenosine deaminase and the cytoplasmic form of superoxide dismutase, respectively, in the segregants. ${ }^{28}$ This analysis showed a positive correlation between the high leucine transport phenotype and the presence of adenosine deaminase activity, or human chromosome 20 (TABLE 1).

TABLE 1. Analysis of Human Chromosomal Marker Enzymes in the Hamster-Human Hybrid Cell Line 158CnpT-1 and Segregants ${ }^{a}$

\begin{tabular}{cccc}
\hline & & \multicolumn{2}{c}{ Presence of Enzyme } \\
\cline { 3 - 4 } Cell Line & $\begin{array}{c}\text { Leucine Transport } \\
\text { Activity }\end{array}$ & $\begin{array}{c}\text { Adenosine } \\
\text { Deaminase }\end{array}$ & $\begin{array}{c}\text { Superoxide } \\
\text { Dismutase 1 }\end{array}$ \\
\hline 158CnpT-1 & high & + & + \\
Segregants & low & - & + \\
11 (class 1) & low & - & + \\
23 (class 1) & high & + & + \\
14 (class 2) & extra-high & + & + \\
15 (class 3) & low & - & + \\
41 (class 4) & & + & + \\
\hline
\end{tabular}

${ }^{a}$ Adenosine deaminase (chromosome 20) and superoxide dismutase 1 (chromosome 21) were assayed as described in MATERIALS and METHODS. 
Segregants in class 3, which had extra-high leucine transport activity, had two copies of chromosome 20, as seen in the karyotype analysis, and also showed greater adenosine deaminase activity. These results allowed us to assign the expression of System L transport activity to human chromosome $20 .^{7}$

\section{CONCLUSIONS}

We have used genetic approaches to study amino acid transport and its regulation with the goal of cloning the transport genes. To this end we have isolated several classes of transport mutants that are described in this report. The increased temperature resistance with higher transport activity, seen in the regulatory mutant cell lines and in the hamster-human hybrid cell lines, supports our assumption that mutant selections could be designed in which growth is limited by leucine transport activity. The low transport mutants that we isolated are being used as the recipient cell lines for DNA transformation in transport gene cloning studies. Transformants containing the transport genes can be selected by raising the temperature, by lowering the leucine concentration, or by a combination of the two. The CHO-ts025 $\mathrm{Cl}$ cell line has been transformed with a human cosmid library and clones have been obtained with increased transport. We are currently attempting to rescue the plasmid containing the human transport genes by a lambda in vitro packaging system. ${ }^{29}$

\section{REFERENCES}

1. Oxender, D. L. \& H. N. Christensen. 1963. J. Biol. Chem. 238: 3686-3699.

2. Christensen, H. N., M. Liang \& E. G. Archer. 1967. J. Biol. Chem. 242: 5237-5246.

3. Shotwell, M. A., D. W. JAYme, M. S. Kilberg \& D. L. Oxender. 1981. J. Biol. Chem. 256: 5422-5427.

4. Bass, R., H. B. HedegaArd, L. Dillehay, J. Moffett \& E. Englesberg. 1981. J. Biol. Chem. 256: 10259-10266.

5. KenNetT, R. H. 1979. Cell Fusion. In Methods in Enzymology. W. B. Jakoby and I. H. Pastan, Eds. Vol. 58: 345-359. Academic Press. New York.

6. Shotwell, M. A., E. J. Collarini, A. Mansukhani, A. E. Hampel \& D. L. Oxender. 1983. J. Biol. Chem. 258: 8183-8187.

7. Lobaton, C. D., A. Moreno \& D. L. Oxender. 1984. Mol. Cell. Biol. 4: 475-483.

8. Gazzola, G. C., V. Dall'Asta, R. Franchi-Gazzola \& M. F. White. 1981. Anal. Biochem. 115: 368-374.

9. FrIeNd, K. K., S. ChEN \& F. H. RUdDle. 1976. Somat. Cell Genet. 2: 183-188.

10. Kozak, C. A., J. B. Lawrence \& F. H. Ruddle. 1977. Exp. Cell Res. 105: 109-117.

11. Guidotti, G. G., A. F. Borghetti \& G. C. Gazzola. 1978. Biochim. Biophys. Acta 515: 329-366.

12. Shotwell, M. A., M. S. Kilberg \& D. L. Oxender. 1983. Biochim. Biophys. Acta 737: $267-284$.

13. Gazzola, G. C., V. Dall'Asta \& G. G. Guidotti. 1981. J. Biol. Chem. 256: 3191-3198.

14. Gazzola, G. C., R. Franchi-Gazzola, P. Ronchi \& G. G. Guidotti. 1973. Biochim. Biophys. Acta 311: 292-301.

15. Moreno, A., C. D. Lobaton \& D. L. Oxender. 1985. Submitted for publication.

16. Thompson, L. H., J. L. Harkins \& C. P. Stanners. 1973. Proc. Natl. Acad. Sci. USA 70: 3094-3098.

17. Hampel, A. E., P. O. RitTer \& M. D. ENGer. 1978. Nature 276: 844-845.

18. Molnar, S. J. \& A. M. Rauth. 1979. J. Cell Physiol. 98: 315-326.

19. MOORE, P. A., D. W. JAYME \& D. L. OXENDER. 1977. J. Biol. Chem. 252: 7427-7430. 
20. Shotwell, M. A., P. M. Mattes, D. W. Jayme \& D. L. Oxender. 1982. J. Biol. Chem. 257: $2974-2980$.

21. Chu, E. H. Y. \& S. S. Powell. 1976. Selective Systems in Somatic Cell Genetics. In Advances in Human Genetics. H. Harris and K. Hirschhorn, Eds. Vol. 7: 189-258. Plenum Press. New York.

22. MoffetT, J. \& E. ENGLeSBerg. 1984. Mol. Cell. Biol. 4: 799-808.

23. Curriden, S. \& E. Englesberg. 1981. J. Cell. Physiol. 106: 245-252.

24. Adair, G. M., L. H. Thompson \& P. A. LiNdL. 1978. Somat. Cell Genet. 4: 27-44.

25. Thompson, L. H., C. P. Stanners \& L. Siminovitch. 1975. Somat. Cell Genet. 1: $187-208$.

26. Giles, R. E., N. Shimizu \& F. H. Ruddie. 1980. Somat. Cell Genet. 6: 667-687.

27. DANA, S. \& J. J. Wasmuth. 1982. Mol. Cell. Biol. 2: 1220-1228.

28. Ferguson-Smith, M. A. \& A. Westerveld. 1982. Cytogenet. Cell Genet. 32: 161-178.

29. El-Gewely, M. R. \& D. L. Oxender. 1985. Ann. N.Y. Acad. Sci. 456: 417-419. This volume.

30. ZAK, B. \& J. Cohen. 1961. Clin. Chim. Acta 6: 665-670. 